\title{
The Roles of Elected Representatives in Political Parties: What's the Challenges?
}

\author{
Malike Brahim ${ }^{1}$ \\ ${ }^{1}$ School of Government, College of Law, Government and International Studies, University of Utara Malaysia \\ Correspondence: Malike Brahim, School of Government, College of Law, Government and International Studies, \\ University of Utara Malaysia, 06010 Sintok, Kedah, Malaysia. Tel: 604-9287925. E-mail: malike@uum.edu.my.
}

Received: March 1, 2017

doi:10.5539/ass.v13n6p55
Accepted: April 17, $2017 \quad$ Online Published: May 31, 2017

URL: https://doi.org/10.5539/ass.v13n6p55

\begin{abstract}
The elected representatives have important roles that involved parliamentary and constituency roles, social services, and to political party. They need to split their time between working in legislative, in constituency and for the party. In Malaysia, elected representatives have important roles in party to affiliate party apparatus, carry out election campaigns, and try to convince voting citizen by casting their ballot for them. The research finding indicated that the parties are due in part to competition for party positions, thus will create money politics and leadership conflicts. Finally, few elected representative hopping to oppose party.
\end{abstract}

Keywords: elected representative, Malaysian politics, political party, roles

\section{Introduction}

Malaysian Parliament consists of the King (Yang di-Pertuan Agong), the Senate (Dewan Negara) and the House of Common (Dewan Rakyat). Malaysia exercised the parliamentary democracy since 1957 and the King is a constitutional monarch. He act as head of the state and the Prime Minister as the head of government. According to Article 40(1), Malaysian Constitution, in exercising his functions, the King must act with the advice of the Cabinet. He is elected among the rulers of the nine Malay states of Malaysia for a five year term (Jewa, Buang \& Merican, 2007; Yusoff, 2006).

Malaysia has a bicameral parliament consisting the upper and lower house. Members of the lower house are elected by the Malaysian citizens for a period of five years for each term (Malaysia, 2007). They come to parliament with expectations to represent the voices of people in their constituency. Meanwhile, members of the upper house are appointed by the King is chosen by thirteen state legislative assemblies. Few of the members in both houses are selected to hold important offices such as the Speaker, Ministers and other positions in government agencies. Therefore, the elected representatives in Malaysia have variety of responsibilities related to the roles their play in politics and administrations.

In facts, the roles of elected representatives often summarized as representative, legislator and scrutinizer of the government. First, the elected representatives have been elected to parliament as representatives of their constituent. They should meet the people in their constituency by regular meeting and activities with high commitments. If they fail to approach, hear and solve the people problems properly, even with sufficient commitment from the party can guarantee a return to parliament at the next election. Secondly, what most people see as the core responsibility of the elected representatives, as legislator or law-maker to pass the legislation in parliament. Thirdly, the roles as scrutinizer to monitor government activities in order to uphold the accountability and transparency. For example, the backbenchers have responsibilities to ensure every policy introduced by government are transparent, accountable and effective, and also criticize weak or bad policy introduced by government. Works as a scrutinizer enables them to complete their duties by monitoring whether the government has correctly used the power. They also should help making the process of governing the country more transparent and accountable to the people who elected them. In Malaysia, they are doing so and have committed to oversight responsibility of ministries, departments and agencies (Brahim, 2015 and 2014).

Basically, the elected representatives find themselves in a web of onerous duties to the nation, to the constituency and political party they represent (Lusoli \& Ward, 2004; Searing, 1994; Stilborn, 2002). As political figures, they need to participate in all deliberations on matter of national and international importance. Therefore, it is so 
important to define the major and secondary roles of elected representatives including their responsibilities to the political party. So, this article attempts to discuss the elected representatives' roles in political party and some problems and challenges they faced as political party's leaders or members.

\section{Roles of Elected Representatives}

As discussed above, the roles of elected representative can be divided into two main categories. First, the fundamental role in parliament. They portray a sovereign representative assembly by performing three central tasks such as to consider, refine and pass legislation; to hold the government accountable for the administration of the laws and authorize the expenditure of required funds; and to determine the life of the government through exercising the ability to provide or withhold support. Furthermore, Aldons (2001) mentioned as legislators, the elected representatives' function in the chamber based on the entitlement to put bills serving the interests of constituents, collectively or individually.

Second, the contemporary role which involves functions as law-making, surveillance, constituency services, and political party responsibilities. For Whittington and Van Loon (1996), they examined that the regular work by elected representatives would be twofold, reflecting to traditional roles as legislator; and implement surveillance roles to monitor the government's administrative performance. More recently, their roles of focusing to constituency service activities and party responsibilities has become their main roles after their role as legislators. Thus, the people have to alert and need to know in details to avoid misunderstanding on the contemporary roles of elected representatives. The law-making functions refer to consider, refine and pass legislation. It is generally seen as less central to their responsibilities, traditional processes in which this was once accomplished persist, and various kinds of legislative and policy influence may be exerted within these processes (Atkinson \& Thomas, 1993). In this processes, they must understand the interests of the citizens whom they represent for example brings up the constituents voice in parliament.

A surveillance activity is a mechanism to monitor, scrutinize, and examine the government activities by elected representative. The purpose of these role is to ensure the government fulfill their promises with proper ways to people and nation. They are involved directly to check any government policies and activities either in the parliament as legislator or in the constituency as representative. Therefore, during the session of parliament, they can debate on any issues for the people interests as a primary contribution to the constituency that they represents (Whittington \& Van Loon, 1996).

Another contemporary role is to service activities. In the constituency, the elected representatives must involve themselves in social works or social service activities to provide assistance to constituents. Social services may require the direct involvement by elected representative in contacting ministers or public service officials, or using time in the House, to inform the grievances of their constituent and seek remedies. These measures have also increased elected representative's potential effectiveness in acting on behalf of constituents who have grievances on issues pertaining to policies and other related matters. Through constituency services, the people can evaluate the performance and contribution of elected representative. This will impact on the people to support them in the coming election.

Duties in political party are also fundamental roles for elected representatives. For example, majority of the elected representatives in Malaysia hold important positions in political party. Therefore, they have big responsibilities in party to ensure they can remain in power to form the government or remain their seats in the House for the coming election. They are representing for all their constituents regardless of their party affiliations (Searing, 1994; Stilborn, 2002). Therefore, Duverger (1972) claimed the political parties have a primary goal to win the election and attain power to form the government. These goals belongs to elected representatives as their duties in parties. They also have a responsibilities to enhance the party image at both national and constituency levels. These issues will be examined in detail based on the research finding which was conducted using questionnaire involving the elected representatives in Malaysia.

\section{Roles in Political Party: What's the Challenges for Elected Representatives?}

Much of the detailed work in making the political parties activities, programs and planning is not fully conducted by party leaders. In contrast, the elected representatives also seek to contribute to party activities and programs. The important role played by elected representatives in order to ensure their party well performs during the elections and gain support from the people. Therefore, political parties developed simultaneously with electoral and parliamentary processes. In other words, political parties are pretty important and as a group of people who come together to contest in the elections and hold key position in the government. According to Hofmeister and Grabow (2011), parties are a distinctive institutions of modern democracy. The party agrees on some proposed policies and programs, with a view to promote the collective good or furthering their supporters' interests to 
government. So, it is hard to imagine the political system functioning effectively without them.

For instance, political parties serve several functions in Malaysian political system includes selecting candidates for elections, select political leaders, mobilize voters, facilitate governance, organize governments and monitor the opposing party in power. In democracy system, the functions of parties and election must come together which is any party can nominate their candidates to contest in any constituencies. The candidates than win seats become an elected representative in the lower house based on the simple first-past-the-post system (Malaysia, 2007). Yet, parties are the major organizations involved in the political process such as the election. The first general election was upheld in 1959 after the independence of Malaysia. Malaysian last general election was the thirteenth, conducted in 2013.

In his debate about elections, Duverger (1972) argued that political activities have a tight linked with the political parties. The parties is a group of people who come together to contest elections and hold power in the government. Therefore, parties are among most important factor affecting people's political participation. At the same time, parties functions to promote the collective good of furthering their supporters' interest to government. In facts, parties play major roles in democratic process around the world. Without political parties, a modern representative democracy such as Malaysia is not conceivable. Only the existences of political parties ensure that the citizens are permanently capable to act politically. They are also the main source for recruiting political leaders. In other words, the party performs several functions (Roskin, Cord, Medeiros \& Jones, 2003) and act as a bridge between the people and government.

Each political party has their own specifics structure and lead by president, deputy or vice president, general secretary and treasurer. They play important roles to encourage talented young leaders to join and hold positions in party. They also have power to recruit candidates to contest in election. The parties are supported by other position in branch (see Table 1) in order to achieve party's objectives to win the election and therefore form the government. Through political parties, people try to fulfill their needs and wishes they heard by government. Today, people have witness the parties have multifunction and contributions to the citizens that are represent by their elected representatives. Therefore, the elected representatives need to spend their times to solve problems which they received in the party office. Thus, they have to split their time between working in parliament, working in the constituency that elected them and working within their party (Rush, 2001). As for the governing party, few of their representatives are selected as ministers with specific responsibilities such as Finance, Home Affairs and so forth.

Table 1. Position in Political Party

\begin{tabular}{cccc}
\hline Level & Position & Frequency & Percentage \\
\hline \multirow{3}{*}{ Branch } & Branch Chief / Woman Chief & 19 & 33.9 \\
& Branch Chairman & 8 & 14.3 \\
& Permanent Chairman & 2 & 3.6 \\
& Committee Member & 2 & 3.6 \\
& Deputy Branch Chief & 1 & 1.8 \\
& Division Chairman & 11 & 19.6 \\
Division & Division Chiefs / Woman Chief & 11 & 19.6 \\
& Deputy Division Chief & 10 & 17.9 \\
& Committee Member & 5 & 9.0 \\
& Secretary & 1 & 1.8 \\
& Committee Members & 4 & 7.1 \\
& Heads of Bureau & 3 & 5.3 \\
& Vice President & 3 & 5.3 \\
Supreme & Supreme Council Member & 2 & 3.6 \\
Council & Senior Vice President & 2 & 3.6 \\
& Youth Chief / Woman Chief & 2 & 3.6 \\
& President & 1 & 1.8 \\
& Deputy President & 1 & 1.8 \\
& Secretary & 1 & 1.8 \\
& Secretary Assistant & 1 & 1.8 \\
\hline
\end{tabular}

Source: Brahim, 2014. 
This part describes the analysis of data followed by discussions of research findings. The findings related to this study research questions. Data were analyzed to identify and describe the roles of elected representatives in political parties. Furthermore, it will examine and ascertain how the elected representatives handle challenges in parties. Data were obtained from self-administered questionnaires, completed by 56 respondents that directly involved as elected representatives. From the survey, it was found that they hold multiple positions at the branch, division and supreme council level in the parties as indicated in Table 1. At the branch level, it is not surprising when the data show majority of elected representatives in Malaysia hold post as branch chief or woman chief (33.9\%), followed by branch chairman (14.3\%). Similarly, at the division level, majority of respondents hold the highest post as division chairman (19.6\%) and division chief (or woman chief) (19.6\%), followed closely by deputy division chief (17.9\%).

The findings also indicated that at the supreme council level, few of respondent's acts as committee members (7.1\%), head of bureau and vice president (both 5.3\%), but only single percent as president, deputy president and secretary. Based on the research findings, it show that the elected representative holds numerous positions to ensure the parties will achieve their aims and it's working effectively to serves the people. Through these positions, they would work closely with the party leaders to attain power and later form government. In Malaysia, they play important roles in assisting party to win the general elections and fulfill their goals to form the government. For the ruling party, they develop policies favorable to their interest or the groups that support them, and organize and persuade voter to elect their candidates to office.

Table 2. Reasons to Join the Political Party

\begin{tabular}{ccc}
\hline Reasons & Frequency & Percentage \\
\hline To protect people's interest. & 50 & 89.3 \\
Personal decisions. & 31 & 55.4 \\
Family's party. & 17 & 30.4 \\
Offered by political party. & 13 & 23.2 \\
Offered by political friends. & 3 & 5.4 \\
Dismissed from previous party. & - & -
\end{tabular}

Source: Brahim, 2014.

The importance of political parties lies in the fact that democracies cannot function without the existence of parties (Goel, 2015). Therefore, questions are asked why individual join parties and what their goals are. There are numerous reasons given for joining parties as indicated in Table 2. From the survey, it was found the majority of respondents had intention to protect the people's interests $(89.3 \%)$, followed closely by their personal decisions $(55.4 \%)$, and continues the family legacies in party (30.4\%). Other reasons were offered from party leaders $(23.2 \%)$ and offered by friends to join the party $(5.4 \%)$. None were sacked from previous party.

Table 3. Goals to an Effort for the Political Party

\begin{tabular}{ll}
\hline Reasons $(\mathrm{N}=56)$ & Party \\
\hline To combat the government officer's power abuse / corruption. & PBB \\
To fight for the future of indigenous groups. & PBB \\
To nurture the religion, nation and state. & UMNO \\
To protect the Malay's rights, interest of Islam and the Malay Rulers. & UMNO \\
To help Anwar Ibrahim. & PKR \\
To transform national politics. & PKR \\
To reform the political system in Malaysia and democratize it. & PKR \\
To form an Islamic state. & PAS \\
To fight for the rights of Muslim groups in Malaysia. & PAS \\
To eradicate oppression by the National Front. & DAP \\
\hline
\end{tabular}

Source: Brahim, 2014.

The elected representatives have goals as for their contributions to the political party. As can be seen from Table 3 , one of the goal is very surprising, to help Anwar Ibrahim, the much influence opposition leader in Malaysia from the People's Justice Party (Parti Keadilan Rakyat [PKR]). They also try to transform the national politics to 
be more democratic than before. According to the respondents from the party of United Indigenous Heritage (Pesaka Bumiputera Bersatu [PBB]), they join political party to fight the indigenous right and to combat government officers' abuse of power and corruption. From United Malays National Organization (UMNO) representatives, they wanted to nurture the religion, nation and state. They wanted to focus on the efforts to protect Malay rights, the interests of Islam and the position of the Malay Rulers in Malaysia. While the Democratic Action Party (DAP) goals to eradicated oppression by the National Front. For the respondents from Pan-Islamic Malaysian Party (Parti Islam Se-Malaysia [PAS]), they have goals to form an Islamic State and fight for the rights of Muslim group in Malaysia.

Table 4. The Sources of Information

\begin{tabular}{ccc}
\hline Sources $(\mathrm{N}=56)$ & Frequency & Percentage \\
\hline Political representative's service center. & 54 & 96.4 \\
Party representatives and agents. & 49 & 87.5 \\
Mass media/press. & 46 & 82.1 \\
Internet. & 44 & 78.6 \\
Party's bureau report. & 22 & 39.3 \\
Public Complaints Bureau. & 8 & 14.3 \\
\hline
\end{tabular}

Source: Brahim, 2014.

Other question asked to the respondents is how they gather information from grass root level. What information do parties' leaders collect from voters? Referring to Table 4, majority the elected representatives $(96.4 \%)$ gather information from the party's service center, followed closely by party agents and representative at grass root (87.5\%). Some of information they collected are from mass media $(82.1 \%)$ and Internet $(78.6 \%)$. From the survey, it was found that new media like Internet and social media namely Facebook, Twitter and Blog play important roles to provide the latest news to people and parties. In facts, the modern technology (information technology or IT) has created a new world where information has become more accessible. For example, the Internet is often used for quick mobilization of interest groups for campaigns. Regarding to Smith and Websterb (2008), the elected representatives are intensive and competent users of ICT, and effectively have positive impression on the quality of their communications. Yet, ICTs are embedded into their parliamentary activities, and email in particular has emerged as a key communication technology. Analysis of the data suggest that the elected representatives need to be encouraged and have more positive view on the potential of technology that would contribute to share any latest news to the mass especially from the constituents.

Furthermore, the elected representatives and politicians have gained another platform to communicate with voter by the party bureau (39.3\%) and Public Complaints Bureau (14.3\%). As shown in Table 4, the elected representatives gather their information from wide variety of sources, not just one. It can be concluded that they need to be aware of the sources of information, and look for opportunities that IT opens for them to get the messages across. Apart from that, voters should not be considered as hinders from their work, but rather a responsibilities for elected representatives to communicate and be close to them. Therefore, Holf (2004) explained ICT have become an indispensable daily tool for the elected representatives. Especially for function such as email, and Internet in general which are used extensively. Other function such as discussion groups, chats, personal homepage and Intranets are less frequently used.

Table 5. Services to Political Party

\begin{tabular}{ccc}
\hline Responsibility $(\mathrm{N}=56)$ & Frequency & Percentage \\
\hline Constructive ideas to political party. & 51 & 91.1 \\
Party member's welfare. & 49 & 87.5 \\
Enhance party membership. & 47 & 83.9 \\
Fully support party leader. & 47 & 83.9 \\
Curb threat from opponent's party. & 43 & 76.8 \\
Solve inner party conflict. & 35 & 62.5 \\
Identify future leaders. & 34 & 60.7 \\
Seek funding and financing. & 27 & 48.2 \\
\hline
\end{tabular}

Source: Brahim, 2014. 
In answering a question about what kind of services or contributions by elected representatives to party, the survey found that they have huge responsibilities (see Table 5). The finding show that an overwhelming percentage of the respondents $(91.1 \%)$ mentioned they are always contribute to gives the constructive ideas for the parties and followed by taking care for the welfare of party members. (87.5\%). Also, the contributions to the parties are to enhance party's membership and fully support to party's leaders (both $83.9 \%$ ). These contributions are very important to increase and preserve public support, and trust to ensure they remains in power for the coming fourteenth general election. According to Genovese and Rioux (2010), the main functions of a party leader is to choose appropriate candidates to win office. The results for thirteenth general election had witnessed support for National Front had been greatly diminished. Therefore, the National Front need to regain support from the public and party members to remain in power. The survey also highlighted the importance of contribution the elected representatives are to protect their party for threat by opponent's party $(76.8 \%)$. Other key tasks of elected representatives in parties include solving party conflict $(62.5 \%)$, to recognize and recruit future leaders $(60.7 \%)$, and seeking funds for the party $(48.2 \%)$.

Nowadays political parties need financial resources in order to carry out their functions effectively, as mentioned above. With enough money, the parties could develop their programs and distribute them, to maintain a stable organization structure, to cultivate communication with the members and conduct electoral campaigns (Hofmeister \& Grabow, 2011). Therefore, elected representatives have duties in order to raise funds, with certain strategies and this should be developed by the treasurer of party. The raising of funds shall be conducted through some strategy including personal pleas for donations that are carried out by leaders and members or by other people close to the party. The parties' leaders can also call people to solicit for donations, organization of specific events than can ask for donations and so forth.

Table 6. Major Problems in Political Party

\begin{tabular}{ccc}
\hline Problems (N=56) & Frequency & Percentage \\
\hline Serious factions. & 36 & 64.3 \\
Struggle for position. & 26 & 46.4 \\
Leadership conflicts. & 19 & 33.9 \\
Money politics. & 18 & 32.1 \\
People's loss of confidence in party. & 14 & 25.0 \\
Party members joining opponents. & 3 & 5.4 \\
Party hopping. & 2 & 3.6 \\
\hline
\end{tabular}

Source: Brahim, 2014.

The survey finding indicates that the services they could contributes for the political party and some challenges they faced as shown in Table 6. Even though parties are an important part of any democratic structure, parties are susceptible to few problems internally. The finding shows that the party disciplines are in deep dissatisfaction and immediate solutions are needed. Respondents agreed (64.3\%) that serious factionalism exists in the party. This problem caused by leadership tussles and competition to occupy important position in parties (46.4\%) thus create leadership conflicts (33.9\%). Hofmeister and Grabow (2011) stated that within parties, conflicts may occur from time to time because of different perceptions on political issues, as well as due to personal rivalries for position and influence. Therefore, to ensure they could hold any positions in parties, unethical approach had been used which is money politics $(32.1 \%)$. With enough money behind them, even a preposterous candidate can at least for a while be a real factor in the nominating contest.

In contrast, Page (2015) said money cannot always buy election results or party annual selection. The effects of money are manifold, subtle and dangerous to the party's solidarity, team spirits, and collaboration. In these issues, it is not a surprising finding why the people loss confidence to the parties and their leaders $(25.0 \%)$. Therefore, they decided to join the opponents' party (5.4\%). For Hofmeister and Grabow (2011), in some countries, especially prominent party members, who might also have parliament mandates or occupy other public offices, have the tendency to leave their parties in cases when conflicts are not resolved in their favor. They said this issue is not only harmful to the party, but also an example of bad democratic behavior. Related to these issues, the finding also indicates those respondents willing to leave the party because all issues and hopping to other party (3.6\%). For example, after $12^{\text {th }}$ Malaysian general elections, few of elected representatives of the People's Coalition - form PKR, DAP and PAS - in Perak State Assembly (PSA) leave their party and declared as Independent but support the National Front. This incident brought the People's Coalition government collapse 
because they lost the majority in the PSA. Instead, the National Front took over the Perak's government as ruling party.

Table 7. Challenges in Political Party

\begin{tabular}{cccc}
\hline Challenges (\%) & Agree & Uncertain & Disagree \\
\hline${\text { Win the } 13^{\text {th }} \text { general election. }}^{\text {Party manifesto implemented fully. }}$ & 92.6 & 1.9 & 5.6 \\
Divide seats fairly. & 92.6 & - & 7.5 \\
Party programs implemented effectively. & 90.8 & 1.9 & 7.5 \\
Government program implemented effectively. & 85.5 & 3.6 & 10.8 \\
Remain people's support. & 85.4 & 3.6 & 10.9 \\
Nomination in $13^{\text {th }}$ general election. & 76.2 & 9.1 & 14.6 \\
Remain position in party. & 53.7 & 20.4 & 26.0 \\
\hline
\end{tabular}

Source: Brahim, 2014.

As we know, political parties are important political organizations in politics. Like other organizations, parties faced various challenges as indicated in Table 7. The finding addresses the major challenge faced by elected representatives was to win the $13^{\text {th }}$ general election in Malaysia. Majority of elected representatives agreed about these constraints $(92.6 \%)$. Yet, before the $13^{\text {th }}$ general election is held, the elected representatives are responsible to ensure all party manifestos which was launched before could be fully implemented (92.6\%). All agendas in the manifesto should be fully implemented, as promised during the last election. People evaluate the progress and performance of each political party, more so for the ruling party and this evaluation directly affect their performance for the next election.

In Malaysian cases, a single political party can never form government alone without supports from other parties. Therefore, an alliance between them is form. It is traditionally seen as the best decision for them to form the government. But, issues always occur among the coalition before election is how to divide the seats fairly $(90.8 \%$ agreed). These issues need to be solved properly to minimize any perceived weakness which is they can work together during the campaign to achieve their aims to win the election. In other words, component parties in coalition must respect each to face their competitor. Therefore, the consensus between component parties in coalition is very important in order to avoid conflicts among themselves and to identify the winnable candidates. These candidates will be nominated for the upcoming general election.

The elected representatives also have burden to ensure all party's programs to be implemented effectively $(85.5 \%$ agreed). It is followed closely in order to ensure the government program implemented effectively $(85.4 \%$ agreed). Hence, the elected representatives have a duty to remain people's support to their party $(76.2 \%$ agreed). Notably, the people have power to determine the elected representatives enable to retain their seats or not. Therefore, they must work hard to ensure that they can be nominated again for the $13^{\text {th }}$ general election $(53.7 \%$ agreed). In Malaysia, almost all party leaders aspired to hold higher positions in the political parties, but half of respondents $(52.8 \%)$ confident that they will retain their position in the next party selection.

According to Hofmeister and Grabow (2011), political parties need strong political leaders. Without leadership quality, parties cannot survive in politics. Therefore, behind all the issues and challenges already discussed, parties need appropriate and attractive political leaders for the citizens and the voters. They would guide the process of forming political opinions and decisions making. The decision made must be legitimate and meticulous. In facts, the political leaders in democracy system such as in Malaysia are empowered by elections as representatives for a five year term. In general, they are the figures, leaders and politicians which steer the development for the nation in term of economy, social and politics. Hence, to achieve these objectives, the elected representatives should demonstrate their capabilities and quality to be leaders.

The issues about political parties and leadership reappears time and time again which need be to solve appropriately in order to consolidate the party. The essential differentiating characteristic of a party is and remains therefore its participation in elections. Even though parties fulfill essential functions for the political system and democracy, they also face unique challenges in modern democracies. Social change and the efficiency (or inefficiency) of dealing with the consequences of changing societies in the political area are the main reasons for these new challenges for political parties (Hofmeister \& Grabow, 2011). 


\section{Conclusion}

As mentioned in discussion above, it is obvious that the elected representatives have huge roles and responsibilities in political parties and contributions to the constituents they represent. However, if any issues or problems that occur cannot be effectively resolved, it will be a liability to the party and the elected representatives themselves. These problems can effect their planning and strategy to win the elections and form a government. Hence, all issues that occur in parties or society whether big or small, need a comprehensive solution. Among the most dreaded problem in party is leadership conflict. Conflict of leadership can be a spark or catalyst to many other problems. Effects of leadership conflict will bring destruction to the party, money politics, corruption, and possibility of leaving the party and joining other party and so forth. Therefore, elected representatives should find out the best solution to avoid conflicts and retain the support of the voters to their party.

Based on the findings, it clearly shows that elected representatives have heavy workload for the parties, parliament, people and government. Here it can be concluded that the roles are very complex and complicate compare to the public officers and corporate members in any company. Therefore, Lusoli and Ward (2004), Malike (2014), Mickel (2010), and Searing (1994) concluded in their study that it is not easy to be an elected representative. They need skills and qualities as leader to manage the parties and run the government or as the opposition in parliament. In other words, role of elected representative should be hold by those who have leadership quality, open-minded, friendly, intelligent, and rational. Therefore, good quality of leadership can be detected from political party to be eligible to nominate in the election. Hence, one of the basic functions of the parties is to recruit (Goel, 2015) and introduce the best leader especially for the younger individuals. If the parties can recruit the best quality of leaders, many benefits can be acquired because they parties will have winnable candidates to contest in any constituencies during the elections. These is the important element that need to be observed to get the people support in the elections.

Many people debated regarding the political parties and elected representatives in the political system. They have close relationship as an essential component of democracy. In facts, parties are the most important platform for people to participate in the political processes (National Democracy Institute [NDI], 2008). At the same time, the parties provided political stability in democratic countries. Regarding to these issues, Goel (2015) argued that the parties in more than one way, unite, simplify and stabilized the political process of the country. After elections, the majority party forms the government and other small parties that won seats in either parliament or state become the opposition. The opposition party keeps a close eye on the working of the ruling party. Hence, healthy opposition is very important for the success of democracy. Here we can look at the traditional and contemporary functions played by elected representatives either they represents the government or opposition party. Yet, the roles that most elected representative fulfills are often summarized as representative, legislator, policy-maker, and scrutinizer of the government.

For Robb (2010), political parties help aggregate segment of the electorate around political, social, and economic issues in democracies. Therefore, the parties and elected representatives have important roles. Genovese and Rioux (2010) found that parties are central figures as representative's in democracy. In Malaysia, political parties offering the elected representatives jobs and position of power because their goals to win election, become the ruling government, and implement their stated policies. It also includes active party members who serve at various levels in leadership positions and those in government office. Parties also help organize government administration and assist people in articulating their positions and needs in a complex society. Meanwhile, parties should run their activities and does not entail a denial of the various functions they have been presumed to fulfill (Schonfeld, 1983). In practices, the parties do not necessarily have to perform any of these roles.

The elected representatives have main tasks to perform all parties' agendas and try to achieve their goals in order to form the government. Hence, as party's leaders, the elected representatives must find ways to incorporate social movements into formal politics. This means that the elected representative need to have connection and ability to utilize social media and other technology to influence the people to support their parties. Furthermore, as party leaders, the elected representatives would act as important figure that respond to specific issues, coalition-building and alignment between parties. This is important to the parties because one party may lack comprehensive ideology and cannot address all issues. They must be aware of what the larger political needs of the followers are, and after election to government, they are able to pass policies that are favorable to the supporters (Robbs, 2010). As party leaders, for example, the National Front would strive to create legislation such as education scholarship, health, living wage and so forth. This indicate that the political parties and elected representatives can offer presents and benefits to followers or supporters. In practices, parties do not necessarily need to perform any of these roles. As party's leaders, all functions in the parties be held by the elected 
representatives. If the elected representative's performs well in order to serve the people, it will give good impacts to the parties - the full gamut of functions attributed to them (Schonfeld, 1983).

There are some important issues which require more in-depth examination for future research on elected representative's roles in the parties and their classic roles in parliament. What this article has done is to summarize the key issues about the roles and challenges faced by elected representatives in the parties which were predominant in the pioneering period and which were perceived to have had some relevance in certain aspects. Secondly, there is also the need to study elected representatives more comprehensively. This work has supplemented previous studies by surveys using the questionnaire with some of these leaders, but still there are gaps to be studied. Most importantly, there has been no attempt to examine in detail the views of these leaders (elected representatives) regarding their tasks and challenges in order to manage the parties.

\section{References}

Aldon, M. (2001). Responsible, representative and accountable government. Australian Journal of Public Administration, 6(1) (March), 34-42. https://doi.org/10.1111/1467-8500.00196

Atkinson, M. M. \& Thomas, P. G. (1993). Studying the Canadian Parliament. Legislative Studies Quarterly, XVIII (3) (August), 423-451. https://doi.org/10.2307/439834

Brahim, M. (2015). Political leadership in Malaysia: Understanding the roles of elected representatives. Kangar, Perlis, Malaysia: University of Malaysia Perlis (UniMAP) Press.

Brahim, M. (2014). Roles and responsibilities of elected representatives in Malaysian political system (Unpublished PhD's thesis), University of Utara Malaysia.

Duverger, M. (1972). Party politics and pressure groups: A comparative introduction. New York: Thomas Nelson and Sons Ltd.

Genovese, M. A. \& Rioux, K. L. (2010). Ethics. In R. A. Couto (Ed.). Political and civic leadership: A reference handbook (pp. 710-719). Los Angeles: SAGE Reference. https://doi.org/10.4135/9781412979337.n79

Goel, A. (2015). Political parties: 5 major functions of political parties in democracy. Retrieved from http://www.importantindia.com/16621/functions-of-political-parties-in-democracy/. (December 13, 2016).

Hofmeister, W. \& Grabow, K. (2011). Political parties functions and organisation in democratic societies. Singapore: Konrad Adenauer Stiftung. $\quad$ Retrieved http://www.kas.de/wf/doc/kas_7671-1442-2-30.pdf?120920114650. (December 12, 2016).

Holf, J. (2004). Member of parliaments' use of ICT in a comparative European perspective. Information Polity, 9 , $5-16$.

Jewa, T. S., Buang, S. \& Merican, Y. H. (Eds.). (2007). Tun Mohamed Suffian's an introduction to the constitution of Malaysia (3rd ed.). Petaling Jaya, Selangor, Malaysia: Pacifica Publications.

Lusoli, W. \& Ward, S. (2004). From weird to wired: MPs, the Internet and representative politics in the UK. Paper presented at the Political Studies Association, University of Lincoln (5-8 April).

Malaysia. (2010). Federal constitution. Petaling Jaya, Selangor, Malaysia: International Law Book Services.

Malaysia. (2007). 50 years democracy and elections in Malaysia. Putrajaya, Malaysia: Election Commission.

National Democratic Institute [NDI]. (2008). The roles and responsibilities of Members of Parliament (MPs): The roles of Parliament in Sierra Leone's democracy. Retrieved December 22, 2010, from https://www.ndi.org/sites/default/files/Sierra-Leone-MP-Roles-Responsibilities-Manual-2008.pdf

Page, B. I. (2015). How money corrupts American politics. Research to Improve Policy and Strengthen Democracy. Scholars Strategy Network. Retrieved December 12, 2016, from http://www.scholarsstrategynetwork.org/how-money-corrupts-american-politics

Robb, D. M. (2010). Political Parties. In R. A. Couto (Ed.). Political and civil leadership: A reference handbook (pp. 396-406). Los Angeles: SAGE Reference. https://doi.org/10.4135/9781412979337.n46

Roskin, M. G., Cord, R., Medeiros, J. A. \& Jones, W. S. (2003). Political science: An introduction (5th ed.). New Jersey: Pearson Education International.

Rush, M. (2001). The role of the Member of Parliament since 1868: From gentlemen to players. Oxford: Oxford University Press. https://doi.org/10.1093/acprof:oso/9780198275770.001.0001

Schonfeld, W. R. (1983). Political parties: The functional approach and the structural alternative. Comparative 
Politics, 15(4) (July), 477-499. https://doi.org/10.2307/421854

Searing, D. (1994). Westminster's world: Understanding political roles. Cambridge: Harvard University Press.

Smith, C. \& Webster, W. R. (2008). The emergent ICT culture of parliamentary: The case of the Scottish Parliament. Information Polity, 13, 249-273.

Stilborn, J. (2002). The roles of the Member of Parliament in Canada: Are they changing? Political and Social Affairs Division, Parliamentary Research Branch (31 May). Retrieved December 22, 2010, from http://www.lop.parl.gc.ca/content/lop/researchpublications/prb0204-e.htm

Whittington, M. S. \& Van Loon, R. J. (1996). Canadian government and politics: Institutions and processes. Toronto: McGraw-Hill Ryerson Ltd.

Yusoff, M. A. (2006). Malaysian federalism: Conflict or consensus. Bangi, Selangor, Malaysia: University of Kebangsaan Malaysia (UKM) Press.

\section{Copyrights}

Copyright for this article is retained by the author(s), with first publication rights granted to the journal.

This is an open-access article distributed under the terms and conditions of the Creative Commons Attribution license (http://creativecommons.org/licenses/by/4.0/). 